\title{
Role of Late Jurassic intra-oceanic structural inheritance in the Alpine tectonic evolution of the Monviso meta-ophiolite Complex (Western Alps)
}

\author{
GIANNI BALESTRO*, ANDREA FESTA*广, ALESSANDRO BORGHI*, \\ DANIELE CASTELLI*, MARCO GATTIGLIO* \& PAOLA TARTAROTTI* \\ * Dipartimento di Scienze della Terra, Università di Torino, Via Valperga Caluso, 35, 10125 - Torino, Italy \\ †Dipartimento di Scienze della Terra, Università di Milano, Via Mangiagalli, 34, 20133 - Milano, Italy
}

(Received 31 October 2016; accepted 2 June 2017; first published online 17 July 2017)

\begin{abstract}
The eclogite-facies Monviso meta-ophiolite Complex in the Western Alps represents a well-preserved fragment of oceanic lithosphere and related Upper Jurassic - Lower Cretaceous sedimentary covers. This meta-ophiolite sequence records the evolution of an oceanic core complex formed by mantle exhumation along an intra-oceanic detachment fault (the Baracun Shear Zone), related to the opening of the Ligurian-Piedmont oceanic basin (Alpine Tethys). On the basis of detailed geological mapping, and structural, stratigraphic and petrological observations, we propose a new interpretation for the tectonostratigraphic architecture of the Monviso meta-ophiolite Complex, and discuss the role played by structural inheritance in its formation. We document that subduction- and exhumation-related Alpine tectonics were strongly influenced by the inherited Jurassic intra-oceanic tectonosedimentary physiography. The latter, although strongly deformed during a major Alpine stage of non-cylindrical W-verging folding and faulting along exhumation-related Alpine shear zones (i.e. the Granero-Casteldelfino and Villanova-Armoine shear zones), was not completely dismembered into different tectonic units or subduction-related mélanges as suggested in previous interpretations. The present-day architecture of the Monviso meta-ophiolite Complex results from nappe-scale folding with a significant component of shearing, and strain partitioning of the Alpine deformation, which were controlled by the inherited occurrence of (i) lateral and vertical variations of facies and thickness of sediments, (ii) an intra-oceanic fault-rock assemblage, which acted as weak horizons in concentrating deformation, and (iii) remnants of a volcanic ridge, which consists of massive metabasalt. Thus, the recognition of pre-collisional, intra-oceanic, tectonostratigraphic inheritance represents an important step in reconstructing the tectonic evolution of meta-ophiolite units in orogenic belts.
\end{abstract}

Keywords: Western Alps, Jurassic Monviso ophiolite, structural inheritance, oceanic core complex, Alpine tectonics

\section{Introduction}

Structural inheritance is a key factor in influencing and controlling the tectonic evolution and structural deformation pattern of orogenic belts during each stage of the Wilson cycle (Wilson, 1966; Dewey \& Spall, 1975), where continents recurrently disintegrate and reassemble, and oceanic crust and lithosphere form, subduct and recycle. Although different contrasting models exist, several studies document the significant role of structural inheritance on the location of extension and continental break-up, rift and passive margin evolution and segmentation (e.g. Dunbar \& Sawyer, 1989; Piqué \& Laville, 1996; Theunissen et al. 1996; Tommasi \& Vauchez, 2001; Petersen \& Schiffer, 2016). Observation that rift propagation is not random but tends to follow the trend of pre-existing orogenic fabrics and plates, systematically reactivating ancient lithospheric structures, provides evidence for the active role played by inherited structures in rift-

$\dagger$ Author for correspondence: andrea.festa@unito.it

Submitted to: GEOLOGICAL MAGAZINE-Special Issue on "Birth and Death of Oceanic Basins" ing processes (e.g. Tommasi \& Vauchez, 2001). In convergent tectonic settings, oceanic extensional detachment faults (e.g. Maffione et al. 2015), as well as fracture zones (e.g. Toth \& Gurnis, 1998; Hall et al. 2003; Leng \& Gurnis, 2011), represent among others, important inherited structures which may provide ideal conditions to nucleate new subduction zones. Oceanic detachment faults, which are commonly associated with oceanic core complexes documented along the slow- (Atlantis Massif, Mid-Atlantic Ridge MAR) and ultraslow-spreading (Atlantis Bank, Southern Indian Ridge - SWIR) ridges (e.g. Cannat, 1993; Tucholke, Lin \& Kleinrock, 1998; Boschi, Früh-Green \& Delacour, 2006; Karson et al. 2006; Dick, Tivey \& Tucholke, 2008; Miranda \& Dilek, 2010), pervasively cut the lithosphere to a depth of 7-8 km (e.g. Dick, Tivey \& Tucholke, 2008; Escartin et al. 2008; Reston \& Ranero, 2011). They represent weakness zones in the lithosphere, characterized by mylonitic to cataclastic shear zones up to hundreds of metres thick and dominated by serpentine minerals and other phyllosilicates (e.g. talc and chlorite; see Boschi, Früh-Green \& Delacour, 2006; Boschi et al. 2013). 

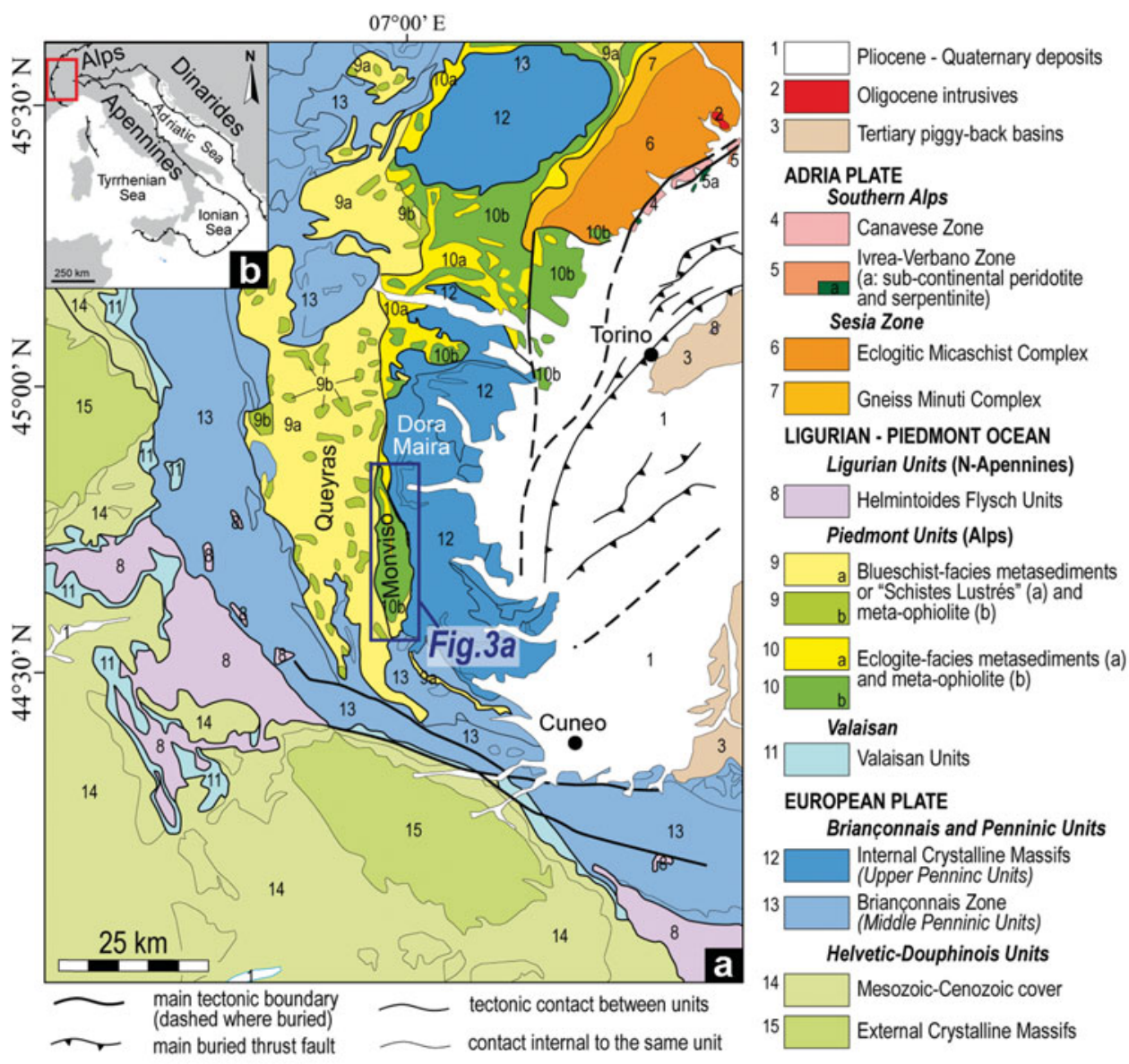

Figure 1. (Colour online) (a) Tectonic map of the Western Alps (modified from Balestro et al. 2015) with the location of the studied sector. (b) Location of map in (a).

These detachment faults are, in fact, ideal pathways for fluid infiltration in the lower crust and upper mantle, triggering hydrothermal alteration and serpentinization (see e.g. Schroeder, John \& Frost, 2002; Mével, 2003; Boschi, Früh-Green \& Delacour, 2006; Boschi et al. 2013).

In the Western Alps, the understanding of the role played by tectonostratigraphic inheritances, in conditioning and controlling their present-day architecture, is often difficult because of the multistage, intense deformation and metamorphic recrystallization they experienced during subduction and subsequent continental collision. As a result, the interpretation of the tectonic evolution of the Western Alps may be partially incomplete, misleading the role played by subductionand collisional-related processes if that of inherited structures is not adequately taken into consideration and understood.

In this paper, we propose a new interpretation for the tectonostratigraphic architecture of the Monviso meta-ophiolite Complex (MO hereafter), which represents one of the best-preserved eclogite-facies ophiolite complexes in the Western Alps (Fig. 1). We present here the first geological map of the whole MO and, on the basis of systematic structural, stratigraphic and petrological observations, we re-interpret its former structural segmentation and partitioning into different Alpine tectonic units. Through the (i) restoration of the meta-ophiolite succession, which is characterized by a fossil mantle-sediment interface, and of preserved unconformities within the metasedimentary succession, and (ii) the detection of the main structures which define the present-day architecture of the MO, we extended our recent published results (Balestro, Fioraso \& Lombardo, 2011; Balestro, Festa \& Tartarotti, 2015; Festa et al. 2015) to the whole MO, documenting that its Alpine tectonic evolution was strongly influenced by its primary intra-oceanic tectonosedimentary physiography. The latter was inherited from the Late Jurassic oceanic core complex formed during extensional tectonics in a slow-spreading system related to the opening of the Ligurian-Piedmont ocean basin (Alpine Tethys). We provide new data to further discuss the role played by the occurrence of a Late Jurassic intra-oceanic 'detachment fault' (see 'Baracun Shear Zone' in Festa et al. 2015) in the Cenozoic Alpine evolution of the MO.

Our data and observations from the MO indicate that apparently incomplete and highly deformed meta-ophiolite sequences that are juxtaposed across major shear zones in high-pressure belts around the world may not exclusively represent the product of subduction-related deformation. The distribution and orientation of seafloor spreading structural 
inheritances with respect to the orientation of the strain field related to subsequent subduction and collisional stages may, in fact, play a significant role in controlling the propagation of subsequent tectonic deformation, isolating and preserving remnants of the pre-orogenic tectonostratigraphic architecture of oceanic basins, and thus providing complementary data to better constrain palaeogeographic reconstructions.

\section{Regional geological setting of the Western Alps and the Monviso Ophiolite}

The Western Alps (Fig.1) resulted from the convergence of the Adria upper plate and the European lower plate with the interposed Ligurian-Piedmont oceanic basin (i.e. the Alpine Tethys; see e.g. Coward \& Dietrich, 1989), which developed as a result of Middle to Late Jurassic rift-drift and seafloor spreading (e.g. Lemoine et al. 1986; Michard et al. 1996; Vissers et al. 2013). The present-day setting of the Western Alps consists of a double verging collisional belt, along which the collisional zone (i.e. the axial sector of the Alpine belt) involves an exhumed fossil subduction complex overthrusting the European foreland and the Adriatic retroforeland, to the $\mathrm{W}$ and $\mathrm{E}$, respectively (e.g. Ricou \& Siddans, 1986; Bigi et al. 1990; Polino, Dal Piaz \& Gosso, 1990). Remnants of the Ligurian-Piedmont oceanic basin correspond to different meta-ophiolite units (i.e. the Piedmont Zone; see e.g. Martin, Tartarotti \& Dal Piaz, 1994; Dal Piaz, Bistacchi \& Massironi, 2003), which are tectonically sandwiched between the European and Adria continental margin units (Fig. 1a), and are classically distinguished into eclogite-facies (i.e. Zermatt-Saas Zone) and blueschist-facies units (i.e. Combin Zone; see Bearth, 1967).

The MO is one of the major and better investigated eclogitized remnants of the Ligurian-Piedmont oceanic lithosphere in the Western Alps (Lombardo et al. 1978; Lombardo, Rubatto \& Castelli, 2002; Balestro, Fioraso \& Lombardo, 2013 and references therein), and is tectonically juxtaposed against the eclogitized Dora Maira Massif, which was part of the European continental margin. A major ductile normal fault (i.e. the West Viso Detachment; Ballèvre, Lagabrielle \& Merle, 1990; Tricart et al. 2004) separates the MO from the overlying Queyras Schistes Lustrés Complex (Fig. 1a). The latter was metamorphosed under blueschist-facies conditions and consists of carbonate-rich metasedimentary rocks with metaophiolite bodies (Tricart \& Lemoine, 1991; Tricart \& Schwartz, 2006). The present-day architecture of the MO resulted from three main tectonic stages (named D1, D2 and D3) developed during (i) the Late Cretaceous to Middle Eocene subduction, (ii) the Late Eocene - Early Oligocene collision and W-verging accretion, and (iii) the Late Oligocene to Neogene westward tilting, which was driven by deep crust/mantle indentation and doming of the underlying Dora Maira Massif (Philippot, 1990; Rosenbaum \& Lister, 2005;
Lardeaux et al. 2006; Balestro, Festa \& Tartarotti, 2015). The D1 was coeval with the subduction-related eclogite-facies metamorphism, and is mainly recorded by an early foliation (i.e. the S1). The S1 overprinted ocean-related structures such as primary stratigraphic surfaces and magmatic foliation (i.e. the S0). The D2 was coeval with the early-exhumation-related blueschist- to greenschist-facies re-equilibration, and was characterized by $\mathrm{W}$-verging non-cylindrical folding associated with shearing. D2 folds are tight to isoclinal and developed an axial plane foliation (i.e. the $\mathrm{S} 2$ ), corresponding to the gently to moderately $\mathrm{W}$ - to SSW-dipping regional foliation, which is parallel to the lithological contacts within the MO and to the basal tectonic contact with the underlying Dora Maira Massif. The D3 developed during late exhumation under lower-greenschist-facies conditions, and consists of open folds, which accommodated westward-extension along major shear zones (e.g. the contact between the MO and the Queyras Schistes Lustrés Complex). During the D3, as a consequence of doming of the Dora Maira Massif, the D1 and D2 structures were tilted.

The MO consists of serpentinite, metagabbros, metabasalt and metasediments (Compagnoni \& Fiora, 1976; Lombardo et al. 1978; MONVISO, 1980). The serpentinite hosts large bodies of $\mathrm{Mg}-\mathrm{Al}$ metagabbro, with minor bodies of Fe-Ti-oxide metagabbro and very minor metaplagiogranite (Castelli, Rostagno \& Lombardo, 2002; Castelli \& Lombardo, 2007; Compagnoni, Rolfo \& Castelli, 2012), which gave Callovian-Oxfordian (163 $\pm 2 \mathrm{Ma}$; Rubatto \& Hermann, 2003) and KimmeridgianTithonian (152 $\pm 2 \mathrm{Ma}$, Lombardo, Rubatto \& Castelli, 2002) crystallization ages, respectively. In the northern sector of the MO, Festa et al. (2015) documented the remnants of an intra-oceanic detachment fault (i.e. the Baracun Shear Zone), which separates massive serpentinite and Middle-Upper Jurassic metagabbros in its footwall from metabasalt and metasediments in its hanging wall. Balestro, Festa \& Tartarotti (2015) highlighted that those metasediments derived from two different successions, consisting of Upper Jurassic calcschist, interfingered by ophiolitederived detrital horizons (i.e. the syn-extensional succession), and Lower Cretaceous carbonate-rich calcschist devoid of any ophiolite-derived material (i.e. the post-extensional succession).

Following Lombardo et al. (1978) and MONVISO (1980), who subdivided the central part of the MO into six main tectonic units on the basis of the occurrence of tectonic contacts among different lithologies (Fig. 2a, b), different authors proposed new subdivisions (see Fig. 2c; e.g. Blake, Moore \& Jayko, 1995; Lombardo, Rubatto \& Castelli, 2002; Angiboust et al. 2012). The estimation of different $P-T$ metamorphic peaks for the tectonic units (Fig. 2c; Blake, Moore \& Jayko, 1995; Messiga et al. 1999; Schwartz et al. 2000; Groppo \& Castelli, 2010; Angiboust et al. 2012) allowed the interpretation that different subduction metamorphic 

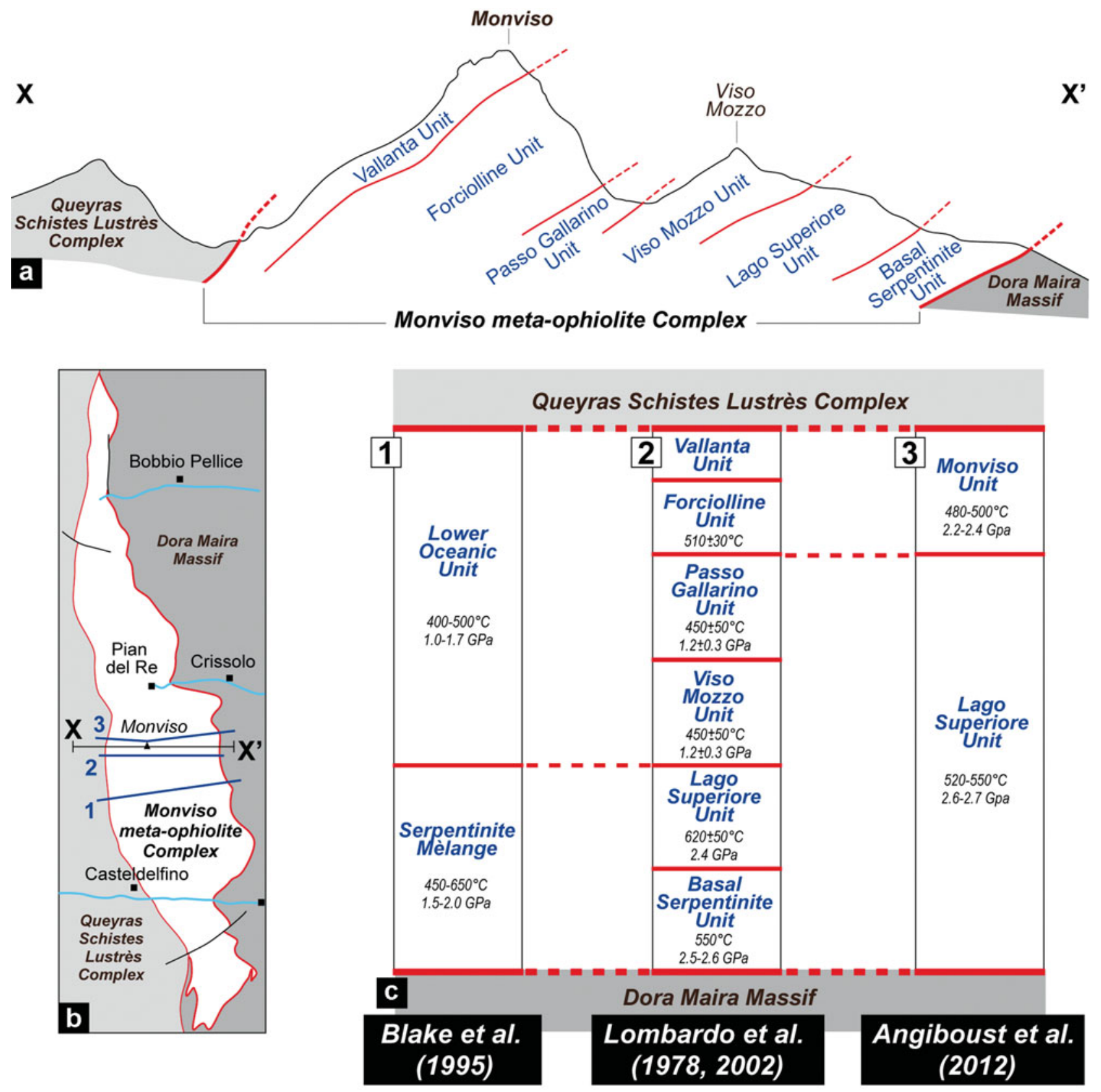

Figure 2. (Colour online) (a) Simplified geological cross-section through the central part of the Monviso meta-ophiolite Complex, showing its early subdivision in different tectonic units according to Lombardo et al. (1978) and Lombardo, Rubatto \& Castelli (2002). (b) Simplified geological map with traces of the geological cross-sections each referring to tectonostratigraphic interpretations and tectonometamorphic data summarized in (c). (c) Correlation between simplified tectonostratigraphic and tectonometamorphic columns of the MO, according to literature; $P-T$ metamorphic peaks from Blake, Moore \& Jayko (1995) (column 1: Lower Oceanic Unit, Serpentinite Mèlange; column 2: Forciolline Unit), Schwartz et al. (2000) (column 2: Passo Gallarino and Viso Mozzo units), Messiga et al. (1999) (column 2: Lago Superiore Unit), Groppo \& Castelli (2010) (column 2: Basal Serpentinite Unit) and Angiboust et al. (2012) (column 3: Monviso and Lago Superiore units).

histories were documented within the MO. However, the structural 'break' separating these different subduction histories was controversially attributed to different tectonic contacts, located in different structural positions (see Fig. 2c).

The inner architecture of the MO is interpreted as either the product of subduction-related or collisionrelated tectonics. For example, Blake \& Jayko (1990) and Guillot et al. (2004) interpreted the MO as a fossilized serpentinite subduction channel, wherein eclogite blocks were tectonically incorporated forming a 'serpentinite mélange'. Alternatively, Angiboust et al. (2011) suggested that the MO corresponds to a primary, almost continuous, fragment of upper oceanic lithosphere subducted at $\sim 80 \mathrm{~km}$ depth and cross-cut by different eclogite-facies shear zones. Finally, Schwartz et al. (2000) proposed that the tectonic juxtaposition of the MO units occurred during collision-related exhumation, under blueschist-facies metamorphic conditions. 


\section{Tectonostratigraphy and structural architecture}

Our geological mapping of the whole MO (1:10000 scale), and detailed structural and lithostratigraphic observations, allow us to re-interpret the tectonostratigraphy of the whole MO (Fig. 3).

\section{3.a. The meta-ophiolite sequence}

Based on the above-mentioned literature data and original observations, the different lithostratigraphic units of the MO (Fig. 3a) are described in the following sections, as pertaining to mantle-derived rocks and syn- to post-extensional sequences (see Balestro, Festa \& Tartarotti, 2015 and Festa et al. 2015), where extension is related to the Late Jurassic rifting and seafloor oceanic spreading of the Ligurian-Piedmont oceanic basin.

\section{3.a.1. Mantle rocks and metagabbro sequence}

This sequence consists of massive serpentinite and metagabbros. The serpentinite (Fig. 4a) is made of antigorite and magnetite and derives from lherzolite and minor harzburgite. The primary mineral assemblage is preserved as relics of clinopyroxene and orthopyroxene porphyroclasts, and as textural relics of spinel and olivine. Rare relics of bastite and lizardite mesh textures highlight that serpentinization of the peridotite began during oceanization. The uppermost part of the serpentinite is locally characterized by the occurrence of both massive and sheared metaophicarbonate (Fig. 4b), which well documents the original exhumation of mantle rocks at the seafloor. The meta-ophicarbonate horizons range from a few metres to a few tens of metres in thickness (e.g. S of Colle di Luca), and consist of irregular calcite and dolomite vein networks which lace around centimetre to decimetre 'clasts' of serpentinite. The massive serpentinite and the meta-ophicarbonate horizons pass upwards into the mylonitic serpentinite and the talc-chlorite schist of the Baracun Shear Zone (BSZ hereafter; see below).

The metagabbros, which were intruded into the original peridotite, range in size from decimetre dykes (Fig. 4a) and pods to hundreds of metres thick and kilometres long bodies. The latter, although also occurring in the northern (i.e. Colle del Baracun area) and southern (i.e. M. Nebin area) sectors of the MO, are more abundant and continuous between Colle Armoine and NE of Casteldelfino (i.e. the central part of the MO; Fig. 3a). In this sector, depending on both the primary tectonostratigraphy and subsequent strain partitioning during Alpine deformation, the metagabbro bodies show different characteristics. Metagabbro occurring ENE of Colle Armoine and between Monviso and P. Caprera, partly preserves its primary intrusive shape and almost shows coarse-grained magmatic fabrics, whereas between Pian del Re and Colle di Luca, metagabbro bodies are elongated in shape and their primary fabric is widely overprinted by Alpine de- formation and recrystallization. In particular, strongly elongated bodies of mylonitic metagabbro (Fig. 4d) occur between $\mathrm{N}$ of Cima delle Lobbie and NE of Casteldefino.

Metagabbros consist of both $\mathrm{Mg}-\mathrm{Al}-$ rich and $\mathrm{Fe}-$ Ti-rich compositions, ranging in texture from coarsegrained pegmatitic to prevalent medium-grained foliated (Fig. 4c). The former (Fig. 4c) is prevalent, showing a mineral assemblage characterized by (i) relics of a magmatic pyroxene almost replaced by $\mathrm{Cr}$ omphacite, (ii) rare relics of magmatic chromite and ilmenite, and (iii) textural relics of the original plagioclase replaced by aggregates of clinozoisite and albite. The olivine-metagabbro, occurring between Monviso and P. Caprera, shows a magmatic fabric with pyroxene of chromian-diopside composition and is characterized by levels of cumulate metatroctolite. The Fe-Ti-oxide metagabbro (Fig. 4d) almost occurs within the $\mathrm{Mg}-\mathrm{Al}$ metagabbro as differentiated pods. It displays a finegrained banded texture and shows relics of a magmatic pyroxene of augite composition, which are retained in a mineral assemblage mainly consisting of garnet, omphacite and rutile (for details see Balestro et al. 2014).

The metagabbro dykes are almost transformed into rodingite (Fig. 4a), mainly consisting of Mg-chlorite, diopside, vesuvianite and garnet of grossular composition. Some rodingite dykes (e.g. E of Casteldelfino and close to Colle di Sampeyre) are poorly deformed and lack the pervasive metamorphic overprint (Bogatto \& Castelli, 1997), highlighting that metasomatism is linked to early oceanic serpentinization.

A tens of metres thick body of medium-grained metaplagiogranite (152 $\pm 2 \mathrm{Ma}$; Lombardo, Rubatto \& Castelli, 2002), which occurs NW of Sampeyre, shows well-preserved intrusive relationships with $\mathrm{Fe}-$ Ti-oxide metagabbro (Fig. 4e). It consists of albite, quartz and jadeite, and is cross-cut by albite-quartzbearing leucocratic dykes (Castelli, Rostagno \& Lombardo, 2002).

\section{3.a.2. Syn-extensional sequence}

This sequence consists of metabasalt (Fig. 4f, g, h) and metasediments. The former, ranging in thickness from a few metres to several hundreds of metres, corresponds to (i) massive aphyric metabasalt, widespread between Monviso and Cima delle Lobbie, (ii) tholeiitic meta-pillow lavas (Fig. 4f) and (iii) brecciated metabasalt (Fig. 4h), grading into volcaniclastic-derived layers. The latter are characterized by a mediumgrained banded texture, which is defined by alternating light-green-yellow layers, mainly consisting of albite, epidote and clinozoisite, and dark-green layers of prevalent $\mathrm{Na}-\mathrm{Ca}$ amphibole. Fine-grained dykes of basaltic composition (Fig. 4g), with well-preserved magmatic relationships, occur within metagabbro $\mathrm{N}$ and E of Viso Mozzo, and between Monviso and P. Caprera.

The syn-extensional metasediments (see also Lagabrielle, 1994) consist of calcschist interbedded with 


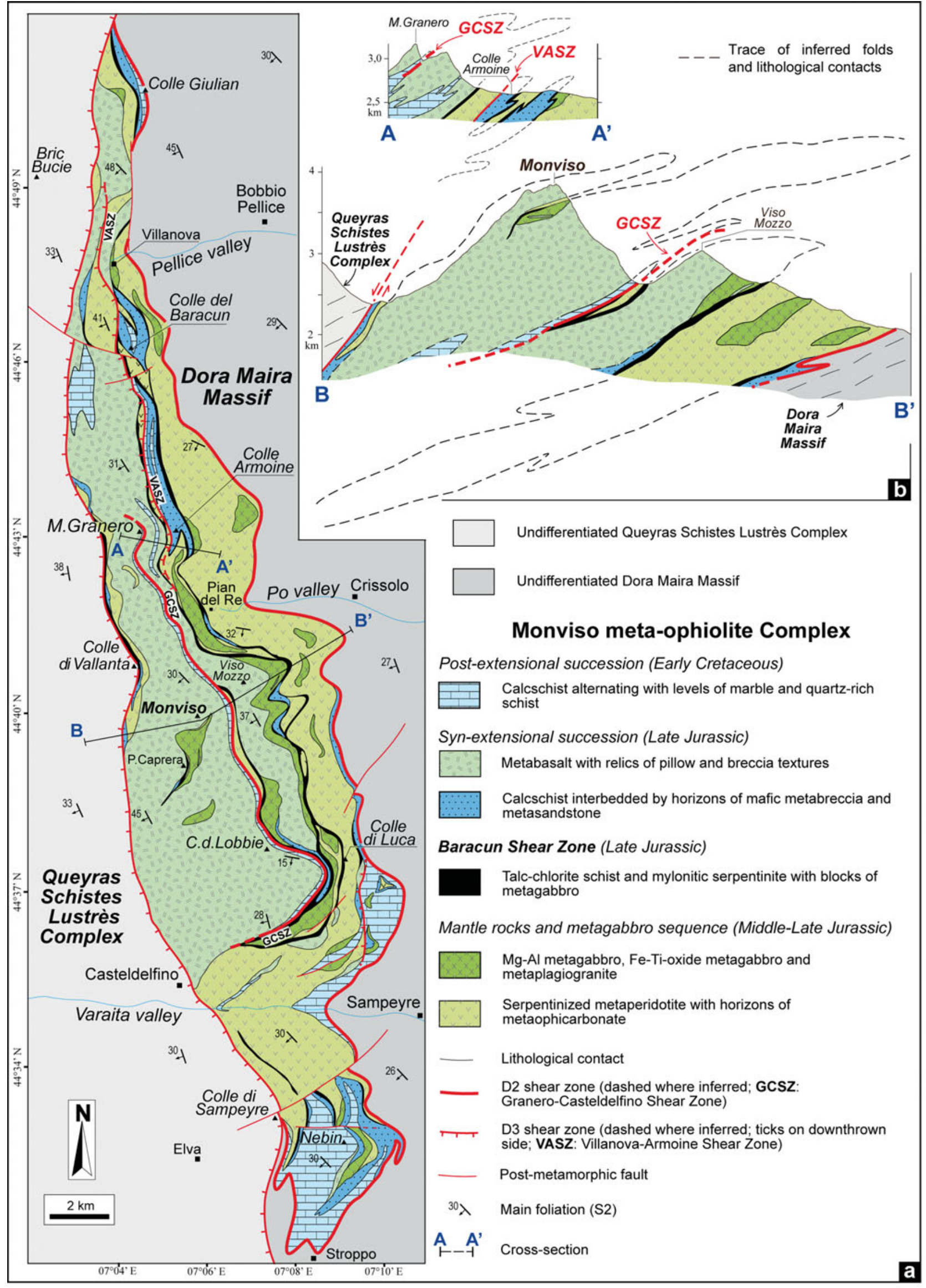

Figure 3. (Colour online) Geological map (a) and representative geological cross-sections (b) of the Monviso meta-ophiolite Complex (note that the scale is different from the map). 

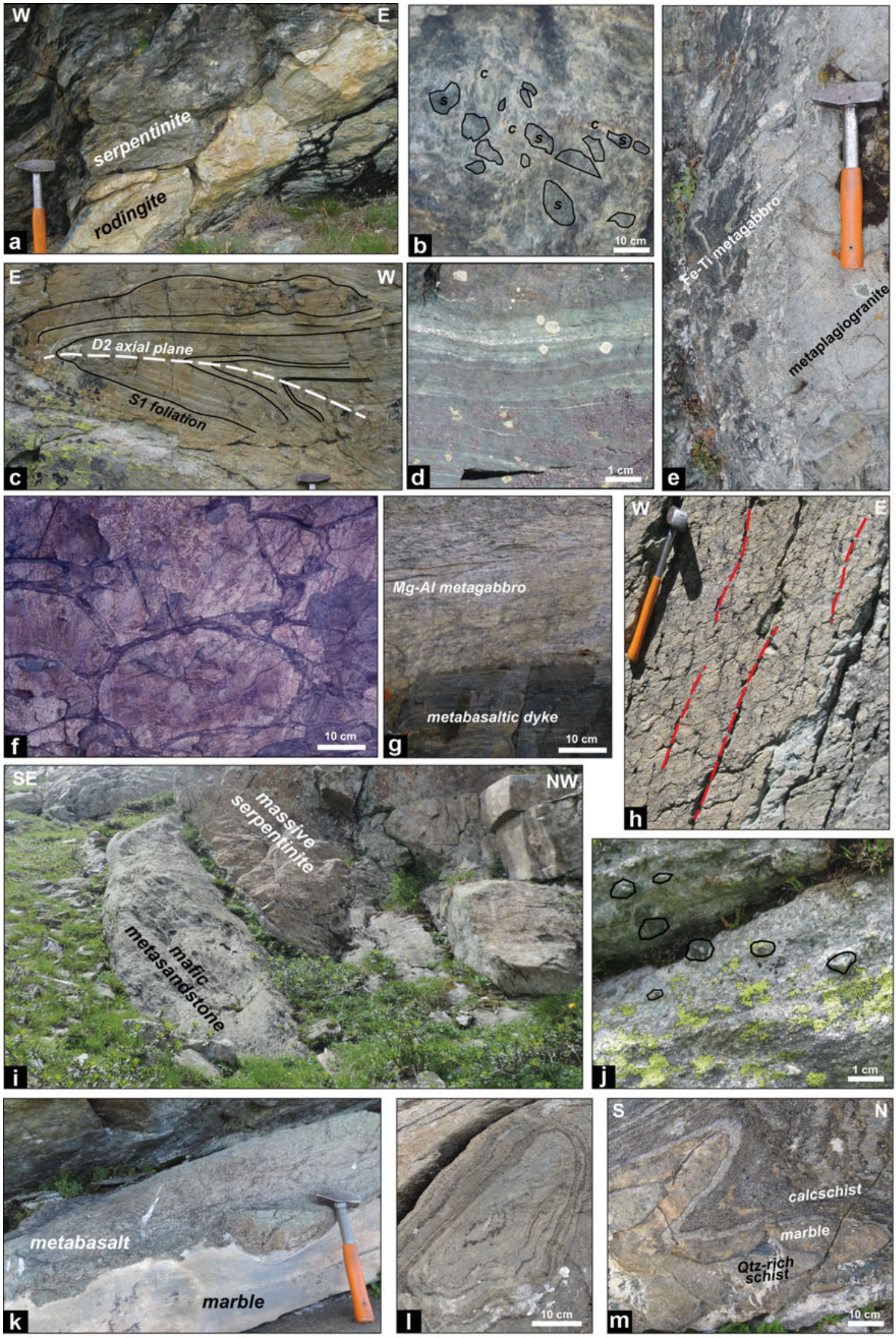

Figure 4. (Colour online) Field images of main lithological units, contact relationships and structures in the mantle rocks and metagabbro, syn-extensional and post-extensional sequences. (a) Rodingitized metagabbro dyke in massive serpentinite (E of Viso Mozzo). (b) Close-up view of a meta-ophicarbonate horizon, consisting of serpentinite clasts (s) meshed in a calcite-dolomite vein network (c) (S of Colle di Luca). (c) $\mathrm{Mg}-\mathrm{Al}$ metagabbro deformed by recumbent D2 folds with stretched and boudinaged long limbs (E of Viso Mozzo). (d) Close-up view of a mylonitic Fe-Ti-oxide metagabbro (NE of Casteldelfino). (e) Preserved magmatic relationship between Fe-Ti-oxide metagabbro and metaplagiogranite (NW of Sampeyre). (f) Metabasalt with well-preserved pillow structure (Colle delle Lobbie). (g) Close-up view of a contact between $\mathrm{Mg}-\mathrm{Al}$ metagabbro and metabasaltic dyke (E of Viso Mozzo). (h) Metabasalt showing relict brecciated texture and penetrative D3 fracture cleavage (dashed lines) (NW of M. Granero). (i) Overturned stratigraphic 
decimetre to sub-decimetre thick horizons of mafic metasandstone and metabreccia (Fig. 4i, j). The calcschist is made of calcite, quartz and white mica, and includes aggregates of white mica, zoisite/clinozoisite and graphite, pseudomorphic after lawsonite, and clast-derived mafic to ultramafic aggregates of $\mathrm{Mg}$ chlorite and Cr-rich white mica (for details see Balestro et al. 2014). The interbeds of mafic metasandstone and metabreccia are of gabbroic composition and commonly show a graded texture. The metabreccia laterally grades, at the tens of metres scale, into metasandstone of the same composition. Clasts of metabreccia are sub-angular in shape and up to a few centimetres in size (Fig. 4j); they consist of aggregates of omphacite, chlorite, Cr-rich white mica and epidote. In addition to these minerals, the matrix is characterized by the occurrence of quartz and white mica. The thickness of the syn-extensional metasedimentary unit shows significant variations towards both $\mathrm{E}-\mathrm{W}$ and $\mathrm{N}-\mathrm{S}$ directions. In the Colle del Baracun, $\mathrm{N}$ of the Colle Armonie and E of the M. Nebin sectors (Fig. 3), it shows an increase in thickness from 0 to about $70 \mathrm{~m}$ towards the $\mathrm{W}$ and away from the underlying talc-chlorite schist of the BSZ (see below).

Although in a few sectors (e.g. NW of M. Granero) metasediments, up to a few metres thick, are stratigraphically interposed between serpentinite and metabasalt, the direct relationships between the thickest syn-extensional metasediment and metabasalt successions are difficult to observe. However, geological mapping suggests a lateral heteropic contact.

\section{3.a.3. Post-extensional sequence}

This sequence is extensively exposed in the southern sector of the MO, while in other sectors it defines narrow horizons, up to a few tens of metres thick. It consists of calcschist devoid of any ophiolite-derived detrital material, and characterized by the occurrence of levels of marble and/or quartz-rich schist, centimetres to decimetres in thickness (Fig. 4k, 1, m). The age of this succession, based on a correlation with the similar unmetamorphosed sediments of the Northern Apennines, was referred to the Early Cretaceous (Lagabrielle, 1994). The calcschist mainly consists of calcite, ankerite, quartz, white mica and epidote, whereas the quartz-rich schist is made of quartz, white mica and chlorite, with minor albite and garnet. In the Colle del Baracun area, the post-extensional metasediments unconformably overlie both the mantle-derived rocks, syn-extensional sequence and rocks of the BSZ (see below). The characteristics of its basal contact, which lacks any Alpine mylonitic structure and superposes the post-extensional metasediments onto different lithostratigraphic units, allowed it to be interpreted as a primary unconformity surface (Fig. 4k). The occurrence of quartz-rich schist levels documents a significant terrigenous input into the basin, showing that the post-extensional sequence consists of distal carbonate and mixed siliciclastic-carbonate turbidites sourced from a continental margin area.

\section{3.b. Architecture of the Monviso meta-ophiolite complex}

The present-day architecture of the MO (Fig. 3b) mainly results from D2 non-cylindrical folding and from shearing along major shear zones of different ages: (i) the ocean-related BSZ (sensu Festa et al. 2015), (ii) the D2-related Granero-Casteldelfino Shear Zone, here defined for the first time, and (iii) the D3related Villanova-Armoine Shear Zone (Fig. 3a).

D2 folds are $\mathrm{W}$-verging and, because of the subsequent D3-related tilting, are characterized by a recumbent geometry (i.e. synformal anticlines and antiformal synclines). They correspond to kilometer macroscale structures which pervasively folded the above-described meta-ophiolite sequence, and are linked with second-order folds occurring at different scales. The core of the synformal anticlines consists of serpentinite, whereas the core of the antiformal synclines consists of metabasalt and metasediments. The best map evidences of D2 folding are the occurrence, in different sectors of the MO (Fig. 3a), of both synextensional and post-extensional metasediments at the top and the bottom (i.e. the overturned ones) of the massive serpentinite (e.g. the M. Nebin area), or the occurrence of serpentinite above the metabasalt (e.g. $\mathrm{N}$ and $\mathrm{S}$ of Colle di Vallanta). Tight to isoclinal D2 folds (Fig. 4m) deform the previous S1-parallel fabric and developed an axial plane foliation (S2). D2 folding is characterized by a strong component of shearing, which is highlighted at the mesoscale by sheath folds (Fig. 41), and by the occurrence of rootless fold hinges and stretched and boudinaged long limbs (Fig. 4c).

\section{3.b.1. The Baracun Shear Zone (BSZ)}

The BSZ (Fig. 3a) extends along the whole MO and, because of pervasive D2 folding (Fig. 5a), it occurs at different structural levels, including the highest one (i.e. $\mathrm{N}$ of Colle di Vallanta; Fig. 5b). It separates mantle rocks and metagabbros in its footwall from the syn-extensional sequence (metabasalt and calcschist with mafic intercalations) in its hanging wall. The Lower Cretaceous post-extensional carbonate-rich calcschist unconformably overlies the BSZ (Fig. 5a) and both the footwall and hanging wall successions,

contact between massive serpentinite and metasandstone of gabbroic composition (NW of M. Granero). (j) Close-up view of a layer of matrix-supported mafic metabreccia characterized by sub-angular clasts of gabbroic composition (Colle del Baracun). (k) Overturned primary contact between the metabasalt of the syn-extensional sequence and the marble of the post-extensional one (SE of Colle di Luca). (1) D2 non-cylindrical fold hinge in a block of post-extensional calcschist (Colle del Baracun). (m) D2 tight folds highlighted by alternating layers of calcschist, marble and quartz-rich schist (Colle del Baracun). Hammer for scale is $30 \mathrm{~cm} l o n g$. 

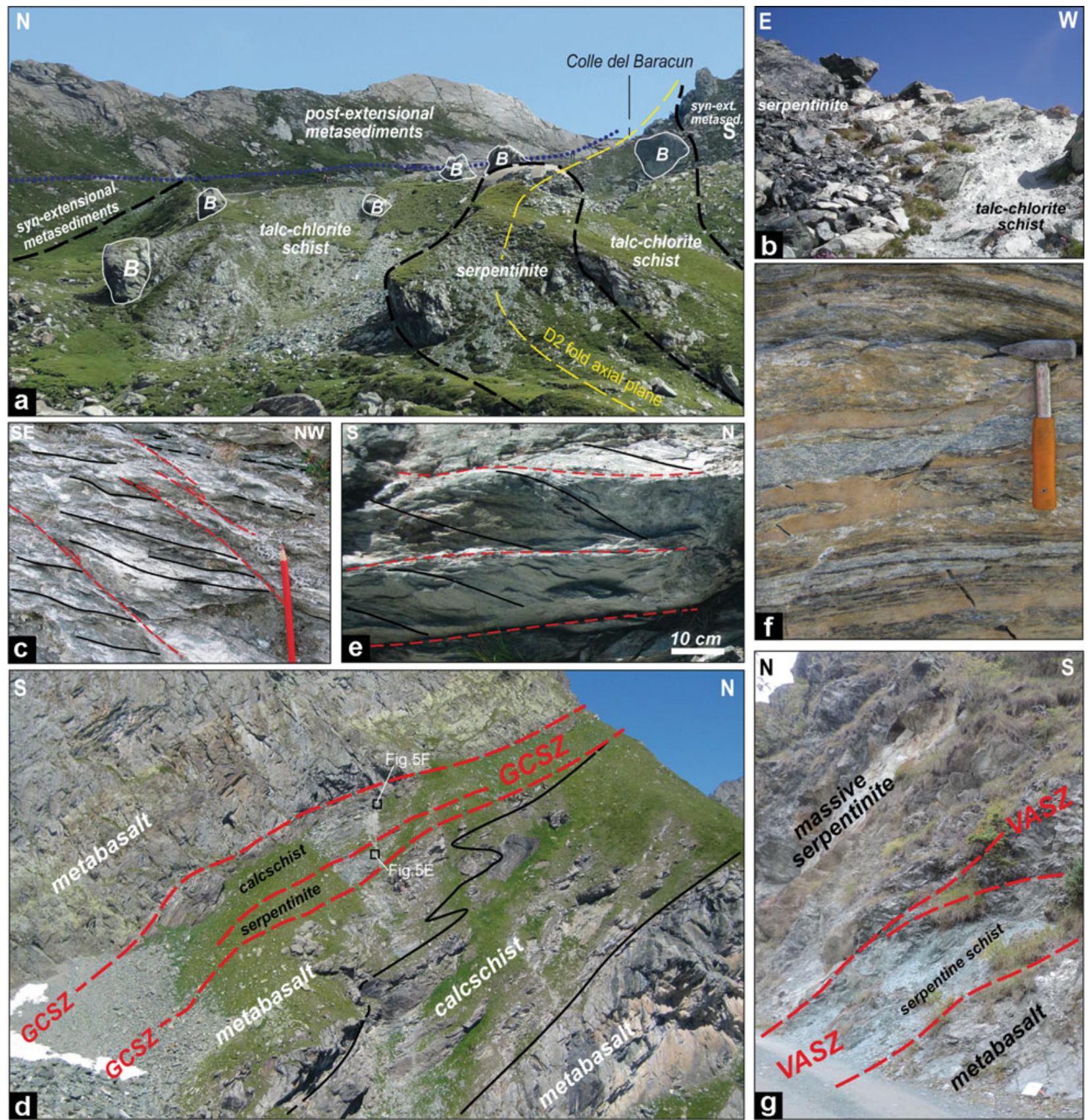

$\mathrm{N}$
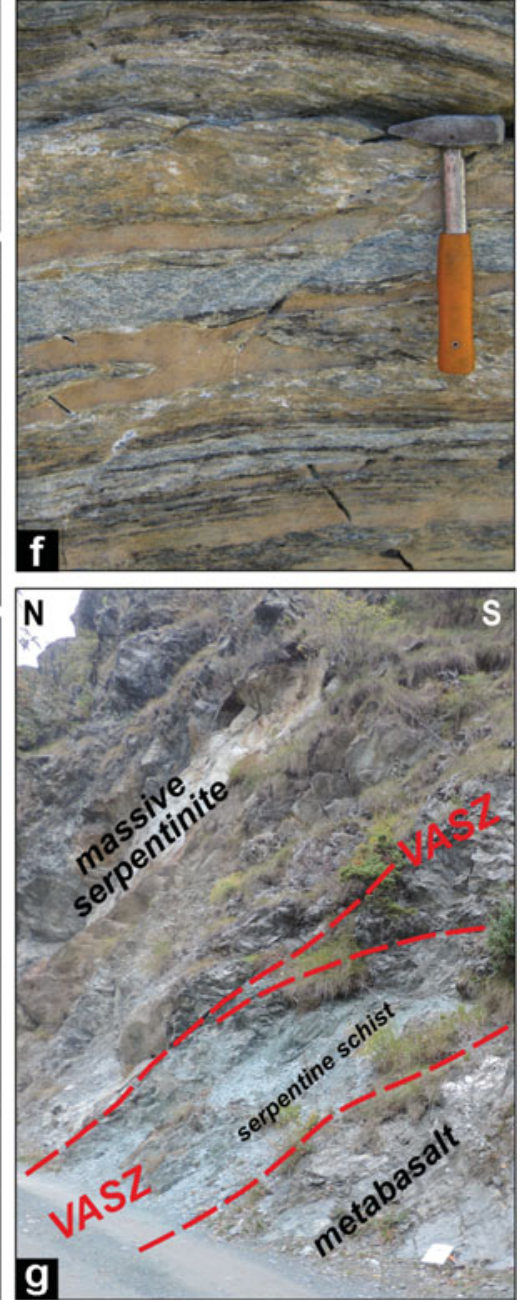

Figure 5. (Colour online) (a) Panoramic view of the folded Baracun Shear Zone at Colle del Baracun: the meta-ophiolite sequence is here deformed by D2 folds and consists of massive serpentinite, talc-chlorite schist embedding blocks (B) of metagabbro (the BSZ), syn-extensional metasediments and post-extensional ones. Note that the post-extensional metasediments rest unconformably (dotted line) on both the syn-extensional ones and the rocks of the BSZ (modified after Balestro et al. 2015). (b) Massive serpentinite and talc-chlorite schist of the BSZ occurring at the top of the MO, along the tectonic contact with the overlying Queyras Schistes Lustrés Complex (W of M. Granero). (c) Close-up view of talc-chlorite-schist of the BSZ, wherein the S2-parallel fabric (black lines) is cross-cut by D3 extensional shear planes (dashed lines) (Colle del Baracun). (d) Panoramic view of the Granero-Casteldelfino Shear Zone: the GCSZ (dashed lines) consists of post-extensional mylonitic calcschist and serpentine schist, and it juxtaposes metabasalt (in the hanging wall) on metabasalt and post-extensional calcschist (in the footwall), deformed by D2 folds (SSW of M. Granero). (e) Close-up view of the serpentine schist of (d), showing the structural relationships between the mylonitic foliation (dashed lines) and the S2 (black lines). (f) Close-up view of the post-extensional mylonitic calcschist of (d). (g) View of the Villanova-Armoine Shear Zone: the VASZ (dashed lines) consists of serpentine schist and juxtaposes massive serpentinite (in the hanging wall) on metabasalt (in the footwall) (NW of Villanova). Hammer for scale is $30 \mathrm{~cm}$ long.

constraining the age of this shear zone to the preEarly Cretaceous (see Balestro et al. 2015). The BSZ consists of metres to tens of metres thick talcchlorite schist and mylonitic serpentinite, embedding blocks of metagabbro (Fig. 5a), decimetres to several metres wide, tectonically wrenched from the footwall mantle-rocks assemblage. This scale-independent, block-in-matrix fabric (sensu Dilek et al. 2012; Festa et al. 2012 and references therein) is significantly devoid of any material derived from the syn- and 
post-extensional sequences. The talc-chlorite schist matrix (Fig. 5c) mainly consists of talc, $\mathrm{Mg}$-chlorite and amphibole of tremolite-actinolite composition, and, among minor minerals, calcite, magnetite, garnet and apatite occur. The associated mylonitic serpentinite mainly consists of antigorite and magnetite, with minor talc, calcite and crysotile. Blocks of metagabbro are mainly of an Fe-Ti-richer composition and consist of omphacite-garnet-and-rutile mineral assemblages, with relics of a magmatic pyroxene of augite composition. The latter locally retains fine inclusions of talc, quartz and, remarkably, Mg-hastingsitic hornblende. In contrast to those occurring in the massive serpentinite, these metagabbros do not show rodingitic metasomatic reactions with the embedding talc-chlorite schist and serpentinite matrix. Blocks of metagabbro were elongated during D1-related stretching deformation and subsequently deformed by D2 folds. The external part of some blocks consists of decimetres thick layers of clast-supported metabreccia of tectonic origin (see Balestro, Festa \& Tartarotti, 2015) in which the clasts have the same gabbroic compositions as the blocks. Observation that the metabreccia is overprinted by S1 foliation and D2 folds at both the micro- and mesoscale constrains brecciation processes to before the D1 phase (for details see Festa et al. 2015). At the microscale, the talc-chlorite schist matrix shows pluri-millimetre thick chlorite-rich and talc-rich domains, which correspond to rootless hinges of D2 folds. Although the BSZ is locally overprinted and reactivated (see below) by Alpine-related deformation, these data overall constrain the BSZ development to before the D1 subduction-related deformation and metamorphic overprint.

\section{3.b.2. The Granero-Casteldelfino Shear Zone (GCSZ)}

The GCSZ (Fig. 3a) is roughly $15 \mathrm{~km}$ long and up to tens of metres thick, and controlled the architecture of the MO. This low-angle W- to SW-dipping (i.e. roughly parallel to the S2 foliation) shear zone (Fig. 5d) superposes two overturned successions which consist of metabasalt and post-extensional metasediments in the hanging wall, and either serpentinite or metagabbro, a BSZ-rocks assemblage, metabasalt and both syn- and post-extensional metasediments, in the footwall. The localization of the GCSZ, along rootless hinges and highly stretched long limbs of second-order D2 folds (Fig. 5d), highlights that it accommodated a component of shearing related to W-verging D2 deformation. The displacement along the GCSZ gradually decreases down to $0 \mathrm{~m}$ towards both the N (i.e. in the M. Granero area) and S (i.e. NE of Casteldelfino), where the shear zone ends within the metabasalt. Remarkably, the evidence that the lateral terminations of the GCSZ roughly correspond to the lateral terminations of the narrow horizons of the post-extensional metasediments, which mark at the base its hanging wall, suggests that shearing was controlled by rheological contrast between those metasediments and the footwall rocks.
At the mesoscale, the GCSZ is defined by centimetres thick shear zones displaying a mylonitic foliation, which is roughly parallel to the S2. These shear zones particularly developed along talc-chlorite schist, mylonitic serpentinite (Fig. 5e) and post-extensional calcschist with levels of marble and quartz-rich schist (Fig. 5f). In these metasediments, the mylonitic fabric almost overprinted the primary compositional banding. Also the metagabbro occurring in the footwall of the GCSZ (e.g. the metagabbro between $\mathrm{N}$ of Cima delle Lobbie and NE of Casteldefino) displays a mylonitic fabric (Fig. 4d). Where the mylonitic foliation and the S2 are not parallelized, the shear zone shows an orientation at a low angle to the S2. The mylonitic foliation generally shows shallow dips to the SW and stretching lineations gently plunging to the SSW. The shear zone usually exhibits a sinistral sense of shear and structural associations (i.e. S-C structures) consistent with top-to-SW kinematics (i.e. consistent with the W-verging D2 folds).

\section{3.b.3. The Villanova-Armoine Shear Zone (VASZ)}

The VASZ (Fig. 3a) corresponds to a few metres thick, W-dipping, extensional shear zone, which displaces by about a few hundred metres both the whole meta-ophiolite sequence and the D2-related structural architecture of the northern sector of the MO. It represents the most persistent D3 structure occurring in the MO and it is well defined by the gradual steepening of the S2 foliation and of the S2-parallel lithological contacts. The VASZ extends for $\sim 10 \mathrm{~km}$ between the Villanova area and Colle Armoine, and, in different sectors, it juxtaposes metabasalt, rocks of the BSZ and narrow massive serpentinite, in the hanging wall, to metabasalt and syn- and post-extensional metasediments, in the footwall (Fig. 5g). It is structurally associated with the D3 tectonic contact which separates the MO and the overlying Queyras Schistes Lustrés Complex. At the mesoscale, D3 deformation consists of widespread fracture cleavages (Fig. 4h) and extensional shear planes (Fig. 5c), millimetres to centimetres thick and centimetres to metres spaced, which are often associated with $\mathrm{W}$-verging open folds (i.e. the D3 folding). These structures mainly developed within postextensional metasediments, which are locally severely reworked by shearing-related deformation. Where they are absent (i.e. $\mathrm{N}$ of Colle del Baracun), shearing is localized along rocks of the BSZ (Fig. 5c). Both shear planes and related slickenside lineations dip moderately to the W. Normal sense of shear is defined by S-C structures.

\section{Discussion}

Our description of the tectonostratigraphic architecture of the MO allows (i) discrimination between inherited intra-oceanic structures and Alpine ones, and (ii) understanding the role of those inherited structures in 


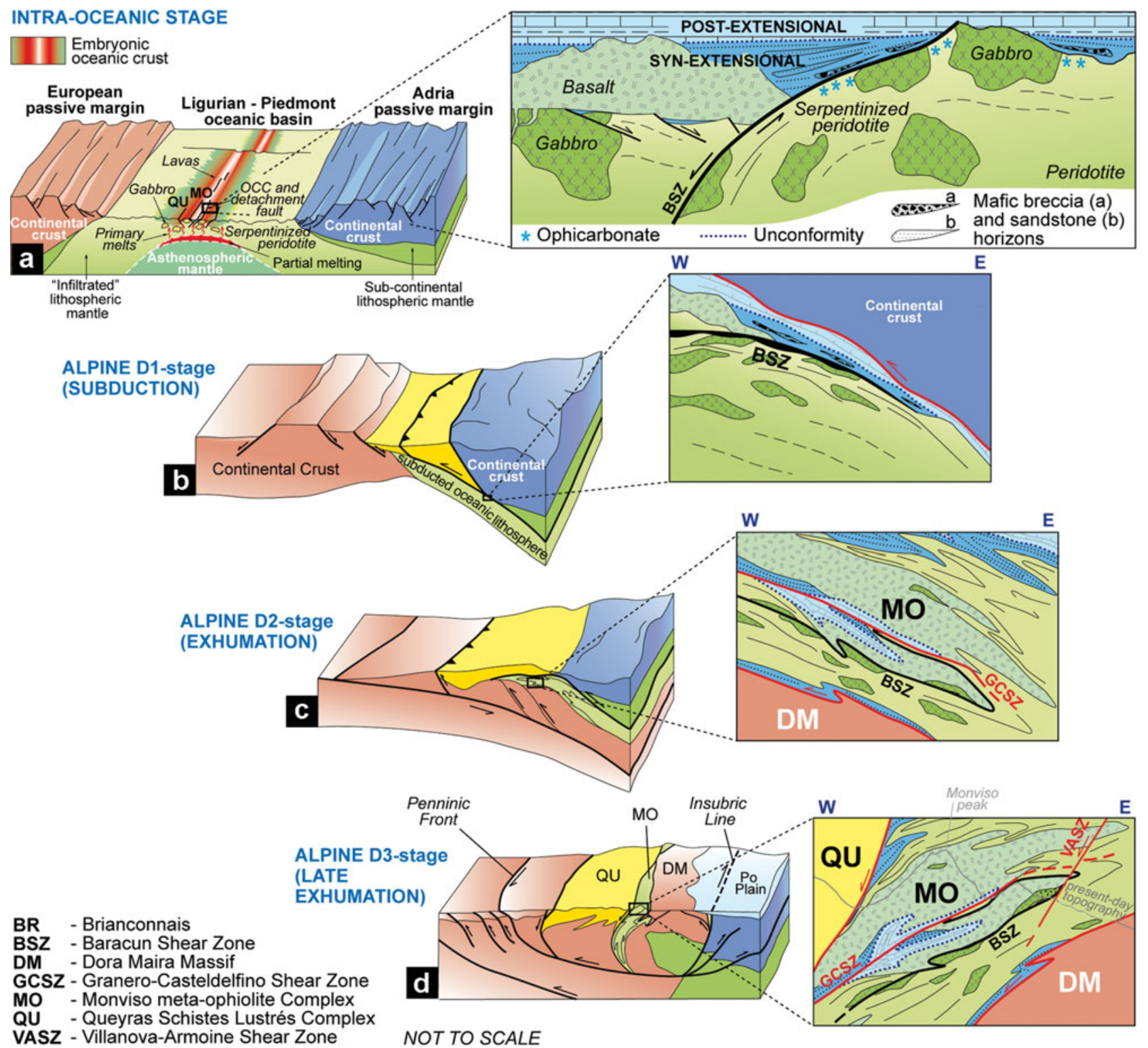

Figure 6. (Colour online) Cartoons showing the different stages of the tectonic and geodynamic evolution of the Monviso metaophiolite Complex from the Jurassic intra-oceanic stage (a) to the Alpine subduction (b), early exhumation (c) and late exhumation (d) stages (modified from Lardeaux et al. 2006; Balestro et al. 2015; Balestro, Festa \& Tartarotti, 2015). See text for explanation. Details of each tectonic and geodynamic stage are represented, showing the role of the inherited intra-oceanic tectonostratigraphic architecture in controlling the subsequent Alpine deformation of the Monviso meta-ophiolite Complex. Detail of (a) is modified from Balestro et al. (2015) and Festa et al. (2015).

controlling the Alpine tectonic evolution of the MO. The addition of these new observations to our published data (Balestro, Festa \& Tartarotti, 2015; Festa et al. 2015) allows us to describe in detail the complete tectonic evolution of the MO from the Late Jurassic seafloor spreading, to subduction, continental collision and exhumation stages.

\section{4.a. Tectonic evolution of the MO and role of inherited structures}

An intra-oceanic tectonic stage and three Alpinerelated ones can be differentiated in the evolution of the MO (Fig. 6).

\section{4.a.1. Seafloor spreading stage and oceanic core complex development}

The early seafloor spreading stage coincided with the production of magma by decompressional melting of the asthenosphere during its slow upwelling. This process led to the intrusion of gabbroic dykes and plutons in an upper mantle, consisting of lherzolite with minor harzburgite. Intrusions mainly consisted of $\mathrm{Mg}-\mathrm{Al}$ gabbro with differentiated pods of $\mathrm{Fe}-$ Ti-richer composition, which crystallized in late Middle Jurassic time (i.e. $163 \pm 2 \mathrm{Ma}$; Rubatto \& Hermann, 2003), and minor Late Jurassic plagiogranite (152 $\pm 2 \mathrm{Ma}$; Lombardo, Rubatto \& Castelli, 2002). Exhumation at the seafloor of both gabbro 
and serpentinized peridotite is highlighted by the occurrence of (i) meta-ophicarbonate at the top of the massive serpentinite, (ii) stratigraphic contacts between syn-extensional/post-extensional metasediments and massive serpentinite, and (iii) intercalations of gabbroic detrital material within the syn-extensional metasediments. This exhumation was driven by the BSZ (Fig. 6a), whose composition and tectonostratigraphic relationships document that it corresponds to an intra-oceanic detachment fault and cannot be interpreted as a subduction-related 'serpentinite mélange' as suggested by some authors (Blake \& Jayko, 1990).

The BSZ controlled seafloor spreading and extensional tectonics by simple shear (Festa et al. 2015); this produced a Late Jurassic oceanic core complex (OCC; see Fig. 6a). The development of the BSZ was promoted by early intrusion of gabbroic bodies and by later serpentinization-related rheological weakening, which was coeval with intrusion of differentiated gabbroic bodies. Continued faulting and a related temperature decrease as the footwall was exhumed, developed the BSZ as a narrow deformation band. When faulting reached a relatively shallow depth $(1-3 \mathrm{~km})$, percolation of seawater down the fault may have induced the hydration of mantle rocks along the shear zone, producing serpentinite and hydrothermal metasomatism, which formed talc-chlorite schist (Balestro, Festa \& Tartarotti, 2015). The latter is well comparable with those observed in hydrothermally metasomatized oceanic rocks along detachment fault zones in the MidAtlantic Ridge (Mével, 2003; Boschi, Früh-Green \& Delacour, 2006), where these rocks are documented to represent weak and highly mobile horizons (e.g. Moore \& Lockner, 2007), able to migrate for long distances along faults and lubricating them (Byerlee \& Brace, 1968; Dengo \& Logan, 1981; Hirauchi, 2006a,b; Dick, Tivey \& Tucholke, 2008). In present-day oceanic core complexes, the highly deformed peridotite and talcchlorite schist associated with detachment faults commonly entrains high-temperature mylonite blocks, produced during the earliest stage of fault nucleation and localized igneous intrusion. Similarly, the BSZ embeds blocks of differentiated metagabbro which are mainly of $\mathrm{Fe}$-Ti-richer composition and locally retain relics of hornblende, which testify to the occurrence of ocean-related medium- $T$ metamorphism, as also documented by Rubatto \& Angiboust (2015). In contrast to those occurring in the massive footwall serpentinite, these metagabbro blocks do not show rodingitic reactions with the hosting rocks (i.e. the talcchlorite and serpentinite schists), highlighting that the original peridotite was already serpentinized at the time of intrusion. The occurrence of tectonic metabreccia in the external part of some metagabbro blocks of the BSZ indicates that this gabbro was exposed along the BSZ, cross-cut and fragmented by brittle faults at shallow structural levels (1-2 km depth). The time constraints for the seafloor spreading stage and oceanic core complex development are provided by the unconformable deposition of Lower Cretaceous post-extensional calcschist (Festa et al. 2015; Tartarotti et al. 2017; see Fig. 6a). Therefore, the extensional stage took place between middle Callovian - early Oxfordian (163 $\pm 2 \mathrm{Ma})$ and middle Kimmeridgian early Tithonian (152 $\pm 2 \mathrm{Ma})$ times.

\section{4.a.2. Alpine-related tectonic stages}

The widespread preserved oceanic tectonostratigraphy highlights that, during convergence-related tectonics (i.e. the D1 stage), the MO was subducted and detached from the main slab as a coherent slice of oceanic lithosphere, a few kilometres thick (Fig. 6b). The whole meta-ophiolite sequence was metamorphosed and sheared under eclogite-facies conditions but not tectonically dismembered into different units or eclogitic blocks in a serpentinite matrix, forming a mélange (i.e. the serpentinite channel of Guillot et al. 2004). The absence of metasediments younger than Early Cretaceous in age suggests that they may have been tectonically delaminated and/or detached at shallow structural levels during the earlier stage of subduction (i.e. Late Cretaceous), without being buried at deeper structural levels along the subduction thrust interface. If compared with the Ligurian Units in the Northern Apennines, which correspond to the nonmetamorphosed succession deposited in the LigurianPiedmont oceanic basin (e.g. Marroni, Meneghini \& Pandolfi, 2010; Festa et al. 2013 and references therein), it is possible to suggest that also in the MO the stratigraphic base of the Upper Cretaceous successions may have acted as a regional-scale detachment level, separating units which were differently (or only in part) involved in the subduction processes.

The occurrence of remnants of an intra-oceanic detachment fault (i.e. the BSZ) and of the related syn-extensional sequence, which are sealed by the Lower Cretaceous post-extensional sequence, highlights that the BSZ was not significantly reactivated during D1 tectonics (Fig. 6b), suggesting that possibly it was not favourably oriented with respect to the orientation of the strain field during subduction. Although primary stratigraphic surfaces (e.g. the S0 sedimentary bedding) were overprinted by the early S1 foliation, the tectonostratigraphic relationships between the primary lithostratigraphic units were mostly preserved (Fig. 6b), and the development of the S1 was almost only associated with stretching and boudinage of the meta-ophiolite sequence. The bestpreserved D1 structures occur at the meso- and microscale. D1 stretching is defined by elongated blocks of metagabbro within the BSZ (Balestro, Festa \& Tartarotti, 2015), whereas boudinage is well highlighted by pinch-and-swell structures and eclogite-facies veining within layered metagabbro (Philippot \& Kienast, 1989). These veins consist of tension gashes and shear fractures filled by omphacite, garnet and rutile, and formed by locally sourced fluids at the peak of the prograde metamorphic path of the MO (Nadeau, Philippot \& Pineau, 1993; Spandler, Pettke \& Rubatto, 2011). 
The subsequent D2 deformation records the continental collisional stage (Fig. 6c), which developed during early exhumation-related metamorphic reequilibration in the epidote-blueschist to greenschistfacies transition (Schwartz et al. 2000; Balestro et al. 2014). This deformational stage played a primary role in forming the present-day structural architecture of the MO (Fig. 6c). D2 folds occur at all scales and developed a pervasive axial plane foliation (i.e. the S2), which is parallel to the lithological contacts. At the macroscale, W-verging noncylindrical D2 folds deformed the inherited tectonostratigraphic setting, forming structures which correspond to present-day synformal anticlines and antiformal synclines (Fig. 6c). Remarkably, the inherited tectonostratigraphic setting did not corresponded to a flat and regular multilayer of mantle rocks, gabbros and overlying sedimentary covers but was characterized by a heterogeneous tectonostratigraphic sequence with lateral and vertical variations of both facies and thickness controlled by intra-oceanic faults (i.e. the BSZ), which strongly controlled D2 folding (Fig. 6c).

Owing to strain partitioning, as well as the differential strength and viscosity of the rocks, some of the metagabbro and massive metabasalt (e.g. the metabasalt occurring in the core of the antiformal syncline) were preserved from the pervasive $\mathrm{D} 2$ deformation, while metasediments and schists of the BSZ were severely deformed. In particular, the BSZ represented a weak horizon along which the highest degree of D2related shearing and folding was concentrated, producing a mylonitic fabric in the talc-chlorite and serpentine schists (Fig. 6c). The occurrence of these mylonites at different structural levels was recognized as Alpinerelated tectonic contacts (Lombardo et al. 1978) and led to the distinction of different tectonometamorphic units in the central sector of the MO (Schwartz et al. 2000; Guillot et al. 2004). Nevertheless, $P-T$ peak estimations across the BSZ are very similar (compare, e.g. Groppo \& Castelli, 2010, Angiboust et al. 2012 and Balestro et al. 2014) and meaningful metamorphic gaps do not occur. Detection of tectonic structures and their relationships with the primary lithostratigraphic units at the scale of the whole MO highlights that the BSZ occurs at different structural levels only because of D2 folding and did not acquire a significant displacement during the subduction and collisional stages.

D2 non-cylindrical folding accommodated a significant component of tectonic shearing. At the macroscale, the most important D2 shearing structure corresponds to the GCSZ, along which the metaophiolite sequence was detached (Fig. 6c), and the hanging wall unit (i.e. metabasalt and post-extensional metasediments) was juxtaposed against the footwall one (i.e. serpentinite, BSZ-rocks and metabasalt). Mesoscale structural observations suggest that the detachment enucleated along hinges and long limbs of second-order D2 folds. Within the folded metaophiolite sequence, two lithological units, correspond- ing to the post-extensional metasediments and the schists of the BSZ, acted as preferred sites for concentration and propagation of deformation (Fig. 6c). The post-extensional carbonate-rich calcschist in the hanging wall was severely stretched and now consists of a narrow zone, suggesting that the rheology of those metasediments controlled the localization and propagation of shearing associated with D2 noncylindrical sheath folding. Notably, the gradual decrease in displacement down to $0 \mathrm{~m}$ of the GCSZ towards both the $\mathrm{N}$ and $\mathrm{S}$ (Fig. 3a) contrasts with its supposed role in juxtaposing two different tectonometamorphic units (i.e. the Upper Shear Zone of Angiboust et al. 2012). The possible interpretation of the GCSZ as a scissor fault accommodating local tearing within the subducted mantle is also to be excluded because of the stratigraphical constraints, which show that roughly the same lithostratigraphic units are juxtaposed along both its hanging wall and footwall. Our new constraints about the GCSZ highlight that it should be interpreted as a D2-related tectonic contact, as also suggested by Schwartz et al. (2000) and Balestro, Fioraso \& Lombardo (2013). Although beyond the aim of this paper, the different $T$ peaks estimated by Angiboust et al. (2012) in the hanging wall ( $T$ peak of $480-500^{\circ} \mathrm{C}$ ) and in the footwall $(T$ peak of $530-550^{\circ} \mathrm{C}$ ) of the GCSZ can be explained by considering that, after subduction, early exhumation of the MO was characterized by a strong decompression and a moderate cooling. Balestro et al. (2014) documented, in fact, that in metasedimentary rocks, occurring close to the tectonic contact with the overlying Queyras Schistes Lustrés Complex, the blueschist- to greenschist-facies metamorphic assemblage is characterized by a $T$ of $500^{\circ} \mathrm{C}$, which is a value very similar to those calculated from metasediments sampled in the hanging wall of the GCSZ. Remarkably, metabasalt sampled away from the shear zone in the hanging wall gave a higher $T$ peak $\left(T=510 \pm 30^{\circ} \mathrm{C}\right.$; Blake, Moore \& Jayko, 1995). The lowest $T$ values from rocks sampled along the GCSZ are, however, an important point of discussion, which would suggest that a specific study about heat transfer across the shear zone and within rocks with different hydromechanical behaviours is needed. As a matter of fact, during continental collision the increase (and decrease) of temperature (and pressure) commonly occurs along significant shear zones which developed in mechanically heterogeneous sequences (see e.g. Li, Gerya \& Burg, 2010; Li, 2014; Reuber et al. 2016). Comparison of available $P-T$ estimates (see Angiboust et al. 2012 with ref., their fig. 9) for the eclogite-facies peak stage in the MO shows that the estimated $P-T$ values are very similar as stated earlier, and differences could be partially related to different approaches used in the calculation.

The D1 and D2 deformation stages were followed by the D3 deformation developed during late exhumation of the MO, under lower-greenschist-facies conditions (Fig. 6d). Folding and shearing occurred in relation to the doming of the underlying Dora Maira 
Massif, which was driven by deep crust/mantle indentation (Lardeaux et al. 2006). This doming caused the progressive westward tilting of the previous D1 + D2 architecture (Fig. 6d). W-verging D3 folds developed in the footwall of new formed extensional shear zones. The main D3 structure corresponds to the VASZ, which cross-cut the meta-ophiolite sequence and the D2-related structural architecture in the northern sector of the MO (Fig. 6d). It is an extensional shear zone that, similarly to the GCSZ, developed along weak lithological contacts such as horizons of different compositions and rheology occurring within both the postextensional metasediments and the BSZ. The VASZ is structurally associated with the tectonic contact which separates the MO from the overlying Queyras Schistes Lustrés Complex (i.e. the West Viso Detachment; Ballèvre, Lagabrielle \& Merle, 1990; Tricart et al. 2004). This tectonic contact is localized along a structural level which corresponds to the overturned limb of the first-order D2 antiformal syncline, and consists of talc-chlorite schist (i.e. the BSZ) and synextensional metasediments resting above metabasalt. Even along the macroscale structures that bound the $\mathrm{MO}$, concentration and propagation of deformation are controlled by the inherited intra-oceanic tectonostratigraphic architecture and related occurrence of weak rocks.

\section{Conclusions}

Although subducted up to eclogite-facies metamorphic conditions, the MO represents a well-preserved continuous fragment of upper oceanic lithosphere and related Upper Jurassic - Lower Cretaceous sedimentary covers, which significantly records the evolution of an oceanic core complex formed by mantle exhumation along an intra-oceanic detachment fault (i.e. the BSZ). The documented Late Jurassic irregular physiography of this sector of the Ligurian-Piedmont basin ocean, which is well comparable with those observed in oceanic core complexes documented along the slow- (Atlantis Massif, Mid-Atlantic Ridge) and ultraslow-spreading (Atlantis Bank, Southern Indian Ridge) ridges (e.g. Cannat, 1993; Tucholke, Lin \& Kleinrock, 1998; Boschi, Früh-Green \& Delacour, 2006; Karson et al. 2006; Dick, Tivey \& Tucholke, 2008; Miranda \& Dilek, 2010), strongly influenced subduction- and exhumation-related Alpine tectonics up to the present-day structural setting of the MO.

Although strongly deformed during the different Alpine stages, the MO was not completely dismembered into different tectonic or tectonometamorphic units as suggested in previous interpretations. The occurrence of remnants of an intra-oceanic Jurassic detachment fault (the BSZ), sealed by the Lower Cretaceous post-extensional sequence, highlights that the BSZ was not significantly reactivated during the subduction-related Alpine stage (D1-related deformation), probably because it was not favourably oriented with respect to the orientation of the strain field.
Conversely, the GCSZ represents a D2-related tectonic contact, developed during the continental collision stage (D2) along a particular detachment level enucleated along the long limb of macroscale D2 folds, conditioned by the inherited heterogeneous Upper Jurassic - Lower Cretaceous tectonostratigraphic physiography of the Ligurian-Piedmont oceanic basin. Its gradual decrease in displacement down to zero towards both the $\mathrm{N}$ and $\mathrm{S}$ and the juxtaposition of the same lithostratigraphic units along both its hanging wall and footwall, invalidate the former inferred role of the GCSZ in juxtaposing two different tectonometamorphic units recording different subduction histories.

Our findings show that recognizing inherited oceanrelated architectures represents a key factor that is useful for reconstructing the whole tectonic evolution of meta-ophiolite units in orogenic belts. Our results demonstrate the importance of carrying out multidisciplinary analytical studies (e.g. structural, stratigraphic, petrological) on detailed geological maps, to fully understand the present-day architecture and the tectonometamorphic evolution of exhumed orogenic belts, and thus to better constrain palaeogeographic reconstructions.

Acknowledgements. This paper is dedicated to the memory of Bruno Lombardo who contributed greatly to advancement of geological knowledge of the Monviso metaophiolite Complex. We thank Editor G. Capponi for his careful editorial handling, and we would like to express our sincere thanks to the two anonymous reviewers for their constructive and thorough reviews, from which we have benefited greatly in revising our manuscript. Research has been supported by the Italian Ministry of University and Research (Cofin-PRIN 2010/2011 "GEOPROB - GEOdynamic Processes of Oceanic Basins" grant no. [2010AZR98L_002] to AF, and grant no. [2010AZR98L_008] to PT); and by the University of Torino (Ricerca Locale "ex 60\%-2014-2015”, Università degli Studi di Torino, to GB).

\section{References}

Angiboust, S., Agard, P., Raimbourgh, H., Yamato, P. \& Huet, B. 2011. Subduction interface processes recorded by eclogite-facies shear zones (Monviso, W. Alps). Lithos 127, 222-38.

Angiboust, S., Langdon, R., Agard, P., Waters, D. \& Chopin, C. 2012. Eclogitization of the Monviso ophiolite (W. Alps) and implications on subduction dynamics. Journal of Metamorphic Geology 30, 37-61.

Balestro, G., Festa, A., Dilek, Y. \& Tartarotti, P. 2015. Pre-Alpine extensional tectonics of a peridotitelocalized oceanic core complex in the late Jurassic, high-pressure Monviso ophiolite (Western Alps). Episodes 38(4), 266-82.

Balestro, G., Festa, A. \& Tartarotti, P. 2015. Tectonic significance of different block-in-matrix structures in exhumed convergent plate margins: examples from oceanic and continental HP rocks in Inner Western Alps (northwest Italy). International Geology Review 57(5-8), 581-605.

Balestro, G., Fioraso, G. \& Lombardo, B. 2011. Geological map of the upper Pellice Valley (Italian Western Alps). Journal of Maps 2011, 634-54. 
Balestro, G., Fioraso, G. \& Lombardo, B. 2013. Geological map of the Monviso massif (Western Alps). Journal of Maps 9(4), 623-34.

Balestro, G., Lombardo, B., Vaggelli, G., Borghi, A., Festa, A. \& Gattiglio, M. 2014. Tectonostratigraphy of the northern Monviso meta-ophiolite complex (Western Alps). Italian Journal of Geosciences 133(3), 409-26.

Ballèvre, M., Lagabrielle, Y. \& Merle, O. 1990. Tertiary ductile normal faulting as a consequence of lithospheric stacking in the western Alps. Mémoire Societé géologique de France 156, 227-36.

BeARTH, P. 1967. Die Ophiolithe der Zone von ZermattSaas Fee. Beiträge zur Geologischen Karte der Schweiz, Neue Folge 132, $130 \mathrm{pp}$.

Bigi, G., Castellarin, A., Coli, M., Dal Piaz, G. V., Sartori, R., Scandone, P. \& VaI, G. B. 1990. Structural Model of Italy, Sheets 1-2. CNR, Progetto Finalizzato Geodinamica. Firenze: SELCA.

BLAKE, M. C., JR. \& JAYKO, A. S. 1990. Uplift of very highpressure rocks in the western Alps: evidence for structural attenuation along low-angle faults. Mémoire Societé géologique de France 156, 237-46.

Blake, M. C., Moore, D. E. \& JaYko, A. S. 1995. The role of serpentinite melanges in the unroofing of ultrahigh-pressure metamorphic rocks: an example from the Western Alps in Italy. In Ultrahigh Pressure Metamorphism (eds R. G. Coleman \& X. Wang), pp. 182-205. Cambridge: Cambridge University Press.

Bogatto, S. \& Castelli, D. 1997. Primary and coronitic to metasomatic mineral assemblages in rodingitic $\mathrm{Mg}$-, $\mathrm{Cr}$ - and $\mathrm{Fe}-\mathrm{Ti}$ gabbros from the Monviso ophiolite (Val Varaita, Italian Western Alps). Quaderni di Geodinamica Alpina e Quaternaria 4, 160-1.

Boschi, C., Bonatti, E., Ligi, M., Brunelli, D., Cipriani, A., Dallai, L., D’Orazio, M., Früh-Green, G. L., Tonarini, S., BARnes, J. D. \& Bedini, R. M. 2013. Serpentinization of mantle peridotites along an uplifted lithospheric section, Mid Atlantic Ridge at $11^{\circ} \mathrm{N}$. Lithos 178, 3-23.

Boschi, C., Früh-Green, G. L. \& Delacour, A. 2006. Mass transfer and fluid flow during detachment faulting and development of an oceanic core complex, Atlantis Massif (MAR $30^{\circ}$ N). Geochemistry, Geophysics, Geosystems 7, Q01104, doi: 10.1029/2005GC001074.

Byerlee, J. D. \& Brace, W. F. 1968. Stick slip, stable sliding, and earthquakes; effect of rock type, pressure, strain rate, and stiffness. Journal of Geophysical Research 73, 6031-7.

Cannat, M. 1993. Emplacement of mantle rocks in the seafloor at Mid-Ocean ridge. Journal of Geophysical Research 98(B3), 4163-72.

Castelli, D., Rostagno, C. \& Lombardo, B. 2002. JdQtz-bearing metaplagiogranite from the Monviso metaophiolite (Western Alps). Ofioliti 27(2), 81-90.

Castelli, D. \& Lombardo, B. 2007. The plagiogranite FeTi-oxide gabbro association of Verné (Monviso metamorphic ophiolite, western Alps). Ofioliti 32, 1-14.

Compagnoni, R. \& Fiora, L. 1976. Sopra una sequenza ofiolitica metamorfica di ultramafiti, gabbri con layering magmatico e basalti a pillow nel Massiccio del M. Viso (Alpi Occidentali). Rendiconti Società Italiana di Mineralogia e Petrologia 32, 699-714.

Compagnoni, R., Rolfo, F. \& Castelli, D. 2012. Jadeitite from the Monviso meta-ophiolite, western Alps: occurrence and genesis. European Journal of Mineralogy 24, 333-43.
Coward, M. P. \& DieTrich, D. 1989. Alpine tectonics - an overview. In Alpine Tectonics (eds M. P. Coward, D. Dietrich \& R. G. Park), pp. 1-29. Geological Society of London, Special Publication no. 45.

Dal Piaz, G. V., Bistacchi, A. \& Massironi, M. 2003. Geological outline of the Alps. Episodes 26, 175-80.

Dengo, C. A. \& Logan, J. M. 1981. Implications of the mechanical and frictional behavior of serpentinite to seismogenic faulting. Journal of Geophysical Research 86, 10771-82.

Dewey, J. \& Spall, H. 1975. Pre-Mesozoic plate tectonics: how far back in Earth history can the Wilson Cycle be extended? Geology 3, 422-4.

Dick, H. J. B., TiveY, M. A. \& Tucholke, B. E. 2008. Plutonic foundation of a slow-spreading ridge segment: oceanic core complex at Kane Megamullion, 23_300N, 45_200W. Geochemistry, Geophysics, Geosystems 9, Q05014, doi: 10.1029/2007GC001645.

Dilek, Y., Festa, A., Ogawa, Y. \& Pini, G. A. 2012. Chaos and geodynamics: mélanges, mélange-forming processes and their significance in the geological record. Tectonophysics 568-569, 1-6.

Dunbar, J. A. \& SAwYeR, D. S. 1989. How preexisting weaknesses control the style of continental breakup. Journal of Geophysical Research 94(B6), 7278-92.

Escartin, J., Smith, D. K., Cann, J., Schouten, H., LANGMuir, C. H. \& Escrig, S. 2008. Central role of detachment faults in accretion of slowspread oceanic lithosphere. Nature 455, 790-4.

Festa, A., Balestro, G., Dilek, Y. \& Tartarotti, P. 2015. A Jurassic oceanic core complex in the high-pressure Monviso ophiolite (western Alps, NW Italy). Lithosphere 7, 646-52.

Festa, A., Dilek, Y., Codegone, G., Cavagna, S. \& Pini, G. A. 2013. Structural anatomy of the Ligurian accretionary wedge (Monferrato, NW-Italy), and evolution of superposed mélanges. Geological Society of America Bulletin 125, 1580-98.

Festa, A., Dilek, Y., Pini, G. A., Codegone, G. \& Ogata, K. 2012. Mechanisms and processes of stratal disruption and mixing in the development of mélanges and broken formations: redefining and classifying mélanges. Tectonophysics 568-569, 7-24.

Groppo, C. \& Castelli, D. 2010. Prograde P-T evolution of a lawsonite eclogite from the Monviso Meta-ophiolite (Western Alps): dehydration and redox reactions during subduction of oceanic FeTi-oxide gabbro. Journal of Petrology 51, 2489-514.

Guillot, S., Schwartz, S., Hattori, K., Auzende, A. \& Lardeaux, J. 2004. The Monviso ophiolitic Massif (Western Alps), a section through a serpentinite subduction channel. In Evolution of the Western Alps: Insights from Metamorphism, Structural Geology, Tectonics and Geochronology (eds M. Beltrando, G. Lister, J. Ganne \& A. Boullier). Journal of the Virtual Explorer 16.

Hall, C. E., Gurnis, M., Sdrolias, M., Lavier, L. L. \& Muller, R. D. 2003. Catastrophic initiation of subduction following forced convergence across fracture zones. Earth and Planetary Science Letters 212, $15-30$.

HIRAUCHI, K. 2006a. Identification of tectonically controlled serpentinite intrusion: examples from Franciscan serpentinites, Gorda, California. Eos Transactions 87(52), Fall Meeting Supplement, Abstract T31C-0463.

HiRAUCHI, K. 2006b. Serpentinite textural evolution related to tectonically controlled solid-state intrusion along the Kurosegawa Belt, northwestern Kanto Mountains, central Japan. Island Arc 15, 156-64. 
Karson, J. A., FrüH-Green, G. L., Kelley, D. S., Williams, E. A., Yoerger, D. R. \& JaKuba, M. 2006. Detachment shear zone of the Atlantis Massif core complex, Mid-Atlantic Ridge, $30^{\circ} \mathrm{N}$ : Geochemistry, Geophysics, Geosystems 7(6), Q06016, doi: 10.1029/20O5GC001109.

LAGABRIELLE, Y. 1994. Ophiolites of the southwestern Alps and the structure of the Tethyan oceanic lithosphere. Ofioliti 19, 413-34.

Lardeaux, J., Schwartz, S., Tricart, P., Paul, A., Guillot, S., Béthoux, N. \& Masson, F. 2006. A crustal-scale crosssection of the south-western Alps combining geophysical and geological imagery. Terra Nova 18(6), 412-22.

Lemoine, M., Bas, T., Arnaud-Vanneau, A., Arnaud, H., Dumont, T., Gidon, M., Graciansky, P. C. DE, Rudkiewicz, J. L., MÉGard-Galli, J. \& Tricart, P. 1986. The continental margin of the Mesozoic Tethys in the Western Alps. Marine and Petroleum Geology 3, 179-99.

LenG, W. \& GuRnis, M. 2011. Dynamics of subduction initiation with different evolutionary pathways. Geochemistry, Geophysics, Geosystems 12, Q12018, doi: $10.1029 / 2011 \mathrm{GC} 003877$.

LI, Z. H. 2014. A review of the numerical geodynamic modeling of continental subduction, collision and exhumation. Science China - Earth Sciences 57(1), 47-69.

Li, Z. H., GerYA, T. V. \& BURG, J.-P. 2010. Influence of tectonic overpressure on P-T paths of HP-UHP rocks in continental collision zones: thermomechanical modelling. Journal of Metamorphic Geology 28, 227-47.

Lombardo, B., Nervo, R., Compagnoni, R., Messiga, B., Kienast, J., Mevel, C., Fiora, L., Piccardo, G. \& LANZA, R. 1978. Osservazioni preliminari sulle ofioliti metamorfiche del Monviso (Alpi Occidentali). Rendiconti Società Italiana di Mineralogia e Petrologia 34, 253-305.

Lombardo, B., Rubatto, D. \& Castelli, D. 2002. Ion microprobe $\mathrm{U}-\mathrm{Pb}$ dating of zircon from a Monviso metaplagiogranite: implications for the evolution of the Piedmont-Liguria Tethys in the Western Alps. Ofioliti 27, 109-17.

Maffione, M., Thieulot, C., van Hinsbergen, D. J. J., Morris, A., Plumper, O. \& Spakman, W. 2015. Dynamics of intraoceanic subduction initiation: 1 . Oceanic detachment fault inversion and the formation of suprasubduction zone ophiolites. Geochemistry, Geophysics, Geosystems 16, doi: 10.1002/2015GC005746.

Marroni, M., Meneghini, F. \& Pandolfi, L. 2010. Anatomy of the Ligure-Piemontese subduction system: evidence from Late Cretaceous-middle Eocene convergent margin deposits in the Northern Apennines, Italy. International Geology Review 52, 1160-92.

Martin, S., Tartarotti, P. \& Dal Piaz, G., V. 1994. The Mesozoic ophiolites of the Alps: a review. Bollettino di Geofisica Teorica e Applicata 36, 175-219.

Messiga, B., Kienast, J. R., Rebay, G., Riccardi, M. P. \& TRIBUZIO, R. 1999. Cr-rich magnesiochloritoid eclogites from the Monviso ophiolites (Western Alps, Italy). Journal of Metamorphic Geology 17, 287-99.

MÉvel, C. 2003. Serpentinization of abyssal peridotite at mid-ocean ridges. Comptes Rendus Geoscience 335, 825-52.

Michard, A., Goffe, B., Chopin, C. \& Henry, C. 1996. Did the Western Alps develop through an Oman-type stage? The geotectonic setting of high-pressure metamorphism in two contrasting Tethyan transects. Eclogae Geologicae Helvetiae 89, 43-80.
Miranda, E. A. \& DileK, Y. 2010. Oceanic core complex development in modern and ancient oceanic lithosphere: gabbro-localized versus peridotite-localized detachment models. Journal of Geology 118, 95-109.

MONVISO. 1980. The Monviso ophiolite complex. In Ophiolites: Proceedings of the International Ophiolite Symposium (ed. A. Panayiotou), pp. 332-40. Nicosia, Cyprus: Geological Survey Department.

Moore, D. E. \& Lockner, D. A. 2007. Comparative deformation behavior of minerals in serpentinized ultramafic rock: application to the slab-mantle interface in subduction zones. International Geology Review 49, 401-15.

Nadeau, S., Philippot, P. \& Pineau, F. 1993. Fluid inclusion and mineral isotopic compositions (HCO) in eclogitic rocks as tracers of local fluid migration during highpressure metamorphism. Earth and Planetary Science Letters 114(4), 431-48.

Petersen, K. D. \& Schiffer, C. 2016. Wilson cycle passive margins: control of orogenic inheritance on continental breakup. Gondwana Research 39, 131-44.

Piqué, A. \& Laville, E. 1996. The central Atlantic rifting: reactivation of Palaeozoic structures? Journal of Geodynamics 21, 235-55.

PhiLIPPOT, P. 1990. Opposite vergence of nappes and crustal extension in the French-Italian Western Alps. Tectonics 9(5), 1143-64.

PhilipPot, P. \& Kienast, J. R. 1989. Chemicalmicrostructural changes in eclogite-facies shear zones (Monviso, Western Alps, north Italy) as indicators of strain history and the mechanism and scale of mass transfer. Lithos 23(3), 179-200.

Polino, R., Dal Piaz, G. V. \& Gosso, G. 1990. Tectonic erosion at the Adria margin and accretionary processes for the Cretaceous orogeny of the Alps. Mémoire de la Société Géologique de France 156, 345-67.

Reston, T. J. \& Ranero, C. R. 2011. The 3-D geometry of detachment faulting at mid-ocean ridges. Geochemistry, Geophysics, Geosystems 12, Q0AG05, doi: 10.1029/2011GC003666.

Reuber, G., Kaus, B. J. P., Schmalholz, S. M. \& White, R. W. 2016. Nonlithostatic pressure during subduction and collision and the formation of (ultra)highpressure rocks. Geology, published online April 2016. doi: 10.1130/G37595.1.

Ricou, L. E. \& SidDans, W. B. 1986. Collision tectonics in the western Alps. In Collision Tectonics (eds M. P. Coward \& A. C. Ries), pp. 229-44. Geological Society of London, Special Publication no. 19.

Rosenbaum, G. \& Lister, G. S. 2005. The Western Alps from the Jurassic to Oligocene: spatio-temporal constraints and evolutionary reconstructions. EarthScience Reviews 69, 281-306.

Rubatto, D. \& Angiboust, S. 2015. Oxygen isotope record of fluid metasomatism during subduction: a P-Ttime-fluid path for the Monviso eclogites (Italy). Contributions to Mineralogy and Petrology 170(5), 44, doi: 10.1007/s00410-015-1198-4

Rubatto, D. \& Hermann, J. 2003. Zircon formation during fluid circulation in eclogites (Monviso, Western Alps): implications for $\mathrm{Zr}$ and $\mathrm{Hf}$ budget in subduction zones. Geochimica et Cosmochimica Acta 67(12), 2173-87.

Schroeder, T., John, B. \& Frost, B. R. 2002. Geologic implications of seawater circulation through peridotite exposed at slow-spreading mid-ocean ridges. Geology 30(4), 367-70.

Schwartz, S., Lardeaux, J., Guillot, S. \& Tricart, P 2000. Diversité du métamorphisme éclogitique dans le 
massif ophiolitique du Monviso (Alpes occidentales, Italie). Geodinamica Acta 13, 169-88.

Spandler, C., Pettke, T. \& Rubatto, D. 2011. Internal and external fluid sources for eclogite-facies veins in the Monviso Meta-ophiolite, Western Alps: implications for fluid flow in Subduction Zones. Journal of Petrology 52(6), 1207-36.

Tartarotti, P., Festa, A., Benciolini, L. \& Balestro, G. 2017. Record of Jurassic mass transport processes through the orogenic cycle: understanding chaotic rock units in the high-pressure Zermatt-Saas ophiolite (Western Alps). Lithosphere 9(3), 399-407.

Theunissen, K., Klerkx, J., Melnikov, A. \& Mruma, A. 1996. Mechanisms of inheritance of rift faulting in the western branch of the East African Rift, Tanzania. Tectonics 15, 776-90.

Toth, J. \& GuRnis, M. 1998. Dynamics of subduction initiation at preexisting fault zones. Journal of Geophysical Research 103, 18053-67.

Tommasi, A. \& Vauchez, A. 2001. Continental rifting parallel to ancient collisional belts: an effect of the mechanical anisotropy of the lithospheric mantle. Earth and Planetary Science Letters 185, 199-210.
Tricart, P. \& Lemoine, M. 1991. The Queyras ophiolite west of Monte Viso (Western Alps): indicator of a peculiar ocean floor in the Mesozoic Tethys. Journal of Geodynamics 13, 163-81.

Tricart, P. \& Schwartz, S. 2006. A north-south section across the Queyras Schistes lustrés (Piedmont zone, western Alps): syn-collision refolding of a subduction wedge. Eclogae Geologicae Helvetiae 99, 429-42.

Tricart, P., Schwartz, S., Sue, C. \& Lardeaux, J. M. 2004. Evidence of synextension tilting and doming during final exhumation from analysis of multistage faults (Queyras Schistes lustrés, Western Alps). Journal of Structural Geology 26, 1633-45.

Tucholke, B., Lin, J. \& Kleinrock, M. C. 1998. Megamullions and mullion structure defining oceanic metamorphic core complexes on the Mid-Atlantic Ridge. Journal of Geophysical Research 103, 9857-66.

Vissers, R. L. M., Van Hinsbergen, D. J. J., MeiJer, P. TH. \& Piccardo, G. B. 2013. Kinematics of Jurassic ultraslow spreading in the Piemonte Ligurian ocean. Earth and Planetary Science Letters 380, 138-50.

WiLson, J. T. 1966. Did the Atlantic close and then re-open? Nature 211, 676-81. 